\title{
Yield and Quality of Triploid Miniwatermelon Cultivars and Experimental Hybrids in Diverse Environments in the Southeastern United States
}

\author{
Richard L. Hassell ${ }^{1,7}$, Jonathan R. Schultheis ${ }^{2}$, \\ Wilfred (Bill) R. Jester ${ }^{3}$, Stephen M. Olson ${ }^{4}$, \\ Donald N. Maynard ${ }^{5}$, and Gilbert A. Miller ${ }^{6}$
}

AdDitional INDEX wORDs. Citrullus lanatus, seedless watermelon, palm melon, cultivar, location effect, genetic expression, environmental effects, cultural practices

\begin{abstract}
Summary. The goal of this study was to evaluate miniwatermelon (Citrullus lanatus) cultivars/experimental hybrids (cultigens) for yield, quality, and adaptability in various growing environments. Eighteen cultigens were evaluated in field locations at southern Florida (Bradenton), northern Florida (Quincy), central South Carolina (Blackville), coastal South Carolina (Charleston), and eastern North Carolina (Kinston). Fruit at each site were harvested when watermelons in several plots were at market maturity. Fruit were categorized as marketable if they weighed between 3.0 and $9.0 \mathrm{lb}$. Fruit were categorized by size as follows: $\leq 3.0 \mathrm{lb}$ (cull), 3.1-5.0 lb, 5.1-7.0 lb, 7.1-9.0 lb, and $\geq 9.1 \mathrm{lb}$ (cull). Fruit were graded according to U.S. Department of Agriculture (USDA) grading standards for all watermelon fruit. We found that eight cultigens (Meilhart, Petite Perfection, Precious Petite, Little Deuce Coupe, RWT 8162, Master, Bibo, and Vanessa) were consistently among the top yielding and four cultigens (HA 5138, HA 5117, Petite Treat, and Valdoria) were consistently among the lowest yielding. These had a consistent yield response regardless of location. Within the small marketable melon category (3.1-5.0 lb), 'Bibo', 'Precious Petite', and RWT 8162 produced a uniform fruit over the five locations. Within the medium marketable melon category (5.1-7.0 lb) 'Meilhart', 'Little Deuce Coupe', HA 5109, 'Xite', 'Mohican', SR 8101, and 'Vanessa' produced uniform fruit size over the five locations. HA 5117, HA 5109, 'Extazy', 'Mohican', 'Petite Treat', and 'Valdoria' produced more fruit in the larger category. Those cultigens that produced melons that were consistently $>9.0$ lb were HA 5138, HA 5117, Bobbie, and Valdoria. The larger USDA marketable class (7.1-9.0 lb) was considered too large to be in the miniwatermelon market. We found five cultigens that provided consistently high soluble solids readings at each location: Master, RWT 8162, Betsy, Bobbie, and Bibo. We sampled only five fruit at each location for internal quality, and found dark seeds in all of the cultigens in at least one of the locations. Rind thickness and fruit shape did not appear to be influenced by test site location.
\end{abstract}

W atermelon acreage is the largest vegetable production acreage in the United States (Lucier and Plummer, 2003). Total

${ }^{1}$ Clemson University, Coastal Research and Education Center, 2700 Savannah Highway, Charleston, SC 29414

${ }^{2}$ North Carolina State University, Department of Horticultural Science, 2721 Founders Drive, Raleigh, NC 27695

${ }^{3}$ North Carolina State University, Department of Horticultural Science, Cunningham Research Station, 202 Cunningham Rd., Kinston, NC 28501

${ }^{4}$ University of Florida, North Florida Research and Education Center, 155 Research Road, Quincy, FL 32351

${ }^{5}$ University of Florida, Gulf Coast Research and Education Center, 14625 CR 672, Wimauma, FL 33598

${ }^{6}$ Clemson University, Edisto Research and Education Center, 64 Research Road, Blackville, SC 29817

${ }^{7}$ Corresponding author. E-mail: rhassel@clemson.edu. annual U.S. watermelon production area ranged from 161 to 231 thousand acres and from $\$ 240$ to $\$ 351$ million from 1994 to 2004 (Arney et al., 2006). Over $80 \%$ of the U.S. watermelon production is concentrated in the southern states of Arizona, California, Florida, Georgia, North Carolina, South Carolina, Oklahoma, and Texas, where temperatures are warmer and growing seasons are longer than in states located in more northern latitudes.

Diploid or seeded watermelons were the only type of watermelons commercially marketed until the 1980s, and fruit averaged at least $20 \mathrm{lb}$. Seeded "ice box" melon cultivars, such as Mickylee and Minilee, were introduced in 1986 (Maynard, 2003) and gained some acceptance in the marketplace. The first commercial triploid hybrids were available in 1951 (Kihara, 1951). Due to difficulties in seed germination and production along with increased seed costs (Hassell and Schultheis, 2002), triploid watermelons were not available commercially until $\approx 1990$ (Maynard, 2001). In spite of the difficulties encountered with triploid watermelon production, the introduction of seedless watermelon to the general public in the United States was initiated in large part by American Sunmelon Seed Co. (Oklahoma City, OK), which provided triploid seeds, and Sun World (Bakersfield, CA), which began a national marketing campaign in the late 1980s. Supply of the specialty fruit was limited, and a premium price was obtained for triploid watermelons, which offset some of the additional costs involved with seed and field production. Consumption of watermelon in the United States increased as a result of triploid watermelon fruit being introduced into the market place (Maynard, 2001). Seedless watermelons are generally smaller in size than seeded watermelons. Over the past 15 years, the

\begin{tabular}{lllc}
\hline $\begin{array}{l}\text { Units } \\
\text { To convert U.S. to SI, } \\
\text { multiply by }\end{array}$ & U.S. unit & SI unit & $\begin{array}{l}\text { To convert SI to U.S., } \\
\text { multiply by }\end{array}$ \\
\hline 0.4047 & $\mathrm{acre}(\mathrm{s})$ & $\mathrm{ha}$ & 2.4711 \\
0.3048 & $\mathrm{ft}$ & $\mathrm{m}$ & 3.2808 \\
0.0929 & $\mathrm{ft}^{2}$ & $\mathrm{~m}^{2}$ & 10.7639 \\
3.7854 & $\mathrm{gal}$ & $\mathrm{L}$ & 0.2642 \\
0.1242 & $\mathrm{gal} / 100 \mathrm{ft}$ & $\mathrm{L} \cdot \mathrm{m}^{-1}$ & 8.0520 \\
2.54 & inch $(\mathrm{es})$ & $\mathrm{cm}$ & 0.3937 \\
0.4536 & $\mathrm{lb}$ & $\mathrm{kg}$ & 2.2046 \\
0.0015 & $\mathrm{lb} / 1000 \mathrm{ft}$ & $\mathrm{kg} \cdot \mathrm{m}^{-1}$ & 671.9658 \\
1.1209 & $\mathrm{lb} / \mathrm{acre}$ & $\mathrm{kg} \cdot \mathrm{ha}^{-1}$ & 0.8922 \\
0.0254 & $\mathrm{mil}$ & $\mathrm{mm}$ & 39.3701 \\
28.3495 & $\mathrm{oz}$ & $\mathrm{g}$ & 0.0353 \\
1.1692 & $\mathrm{pt} / \mathrm{acre}$ & $\mathrm{L} \cdot \mathrm{ha}^{-1}$ & 0.8553 \\
$\left({ }^{\circ} \mathrm{F}-32\right) \div 1.8$ & ${ }^{\circ} \mathrm{F}$ & ${ }^{\circ} \mathrm{C}$ & $\left(1.8 \times{ }^{\circ} \mathrm{C}\right)+32$
\end{tabular}


introduction of new triploid hybrids with improved seed germination and improved production practices have resulted in increased cost-effective, seedless watermelon production (Maynard and Elmstrom, 1992; Motsenbocker and Arancibia, 2002; NeSmith and Duval, 2001; Walters, 2005 ). Seedless watermelon production now comprises $>70 \%$ of the watermelon shipments in the United States (USDA, 2004). In some areas of the United States, buyers will purchase only seedless watermelons. Most of the seedless watermelons sold range in size from 12 to $18 \mathrm{lb}$. During the past 20 years, the preferable market size of watermelons has decreased (L. Coleman, personal communication).

Beginning in 2003, seedless miniwatermelons were introduced by Syngenta Seeds (Boise, ID), and Seminis (Oxnard, CA), companies (Barboza, 2003). Miniseedless ranged in size from 3.0 to $7.0 \mathrm{lb}$ (Barboza, 2003). Initially, the seedless miniwatermelon developed by Seminis, was sold under the Bambino trade name and marketed by Six Ls Produce (Immokalee, FL). Currently, this particular miniwatermelon is available to all commercial growers. Syngenta Seeds, has several seedless miniwatermelon cultivars that are sold under the PureHeart trademark by Dulcinea Farms (Davis, CA). Only growers with a contract are permitted to grow the cultivars sold under the PureHeart Trademark. Seedless miniwatermelons are also marketed and referred to as palm or personal-size melons and may range in size up to 9 lb. Producers generally receive a higher price per pound for seedless watermelons. Producers could potentially receive even greater premiums for the seedless miniwatermelons than traditional-size seedless watermelons (Marr and Gast, 1991). Based on a survey conducted by the National Watermelon Promotion Board, the availability of seedless miniwatermelons has led to additional watermelon sales (L. Coleman, personal communication). The seedless miniwatermelon market segment has not usurped sales of traditional-size seedless watermelons.

With the growing market appeal for miniwatermelons, seed companies have recently introduced many miniwatermelon cultivars. The goal of this study was to evaluate miniwatermelon cultigens for yield, internal quality, and adaptability in various growing environments.

\section{Materials and Methods}

All Locations. The seedless miniwatermelon seeds were obtained from several companies (Table 1 ). In 2004, 18 cultigens (Table 1) were evaluated in field locations at southern Florida (Bradenton), northern Florida (Quincy), central South Carolina (Blackville), coastal South Carolina (Charleston), and eastern North Carolina (Kinston).

Ten plants were planted in a onerow 15-ft-long plot, replicated three times in a randomized completeblock design. Plots with missing plants were replanted $\approx 7 \mathrm{~d}$ after planting to achieve $100 \%$ stand in most cases. Spacing between row middles was $9 \mathrm{ft}$, while in-row spacing was 18 inches. Pollenizer plants of SP-1 (Syngenta Seeds) were interplanted in the plots between treatment plants 1 and $2 ; 4$ and 5 ; and 7 and 8 . Standard cultural practices, specific to the location, were used during the growing season (Olson and Simonne, 2004; Sanders, 2004).

Yield data were grouped by harvests; however, only cumulative harvest yields are presented. Fruit at each site were harvested when watermelons in several plots were at market maturity. Each fruit was weighed, and total weight was recorded. Fruit were categorized as marketable if they weighed between 3.0 and $9.0 \mathrm{lb}$. Within this range, further categories were divided as follows: $\leq 3.0 \mathrm{lb}$ (cull), 3.1-5.0 lb, 5.1-7.0 lb, 7.1-9.0 lb, and $\geq 9.1 \mathrm{lb}$ (cull). These categories were determined based upon discussions with seed-company representatives and participating scientists. The upper size limit for marketable miniwatermelon fruit $(7.1-9.0 \mathrm{lb})$ is $2 \mathrm{lb}$ greater than fruit considered marketable by Dulcinea Farms (Barboza, 2003 ); however, other seed companies suggested that this category should be considered a marketable miniwatermelon. Average fruit size was determined for each cultivar. The number of harvests varied depending on location.

Quality measurements were taken on five randomly selected marketable miniwatermelon fruit from each plot. Each miniwatermelon was cut from stem end to blossom end before quality data were taken. A fresh sample was obtained from the center of the mesocarp of each watermelon, and total soluble solids were measured using a digital refractometer (Reichert Scientific Instruments, Buffalo, NY). Rind thickness was recorded to the nearest $1 / 8$ inch, on four regions of the fruit, starting at the stem end, and thereafter every $90^{\circ}$. The occurrence of hollow heart (Maynard, 2001), for each fruit, was obtained with length and width measurements to the nearest $1 / 8$ inch. Fruit shape was obtained by measuring the length and width of five fruit. The length-to-width diameter ratio was calculated, and a rating of 1 indicated the fruit was round, while a rating nearer 2 indicated the fruit was oblong. Triploid watermelons are generally seedless, but dark, hard seedcoats have been reported to form within the flesh of the fruit (Maynard and Hopkins, 1999). These objectionable seedcoats are known to be partially related to the environment (Maynard, 2001); therefore, we felt it should be recorded. The presence of dark seedcoats was recorded by using the following index rating: 0 , no seedcoats; $1,<10$ seedcoats; $2,>10$ but $<50$ seedcoats; $3,>50$ seedcoats. Most quality measures were taken at first harvest. Fruit were graded according to USDA grading standards for all watermelons (USDA, 1978).

Data from all locations were combined, and statistical analysis was conducted using SAS (version 8; SAS Institute, Cary, NC). The experimental design was a randomized complete-block design. Analysis of variance was conducted for yields and quality data. Means were separated for cultigens using least significant differences (LSD) at the $1 \%$ and $5 \%$ levels of significance.

Kinston, NC. Seeds were sown into transplant trays (LE 1803; Landmark Plastics Corp, Akron, OH) on 6 Apr. 2004. The planting medium used for transplants was Fafard 4P (Conrad Fafard, Inc., Agawam, MA). The transplants were grown for 6 weeks using the seedless watermelon transplant production recommendations (Hassell and Schultheis, 2002). About 3-4 weeks after seeding, the plants were placed in a coldframe and hardened before being transplanted in the field on 13 May 
Table 1. Seed sources and fruit descriptions of triploid miniwatermelon cultivars and experimental hybrids evaluated in 2004 at five locations within the southeastern United States.

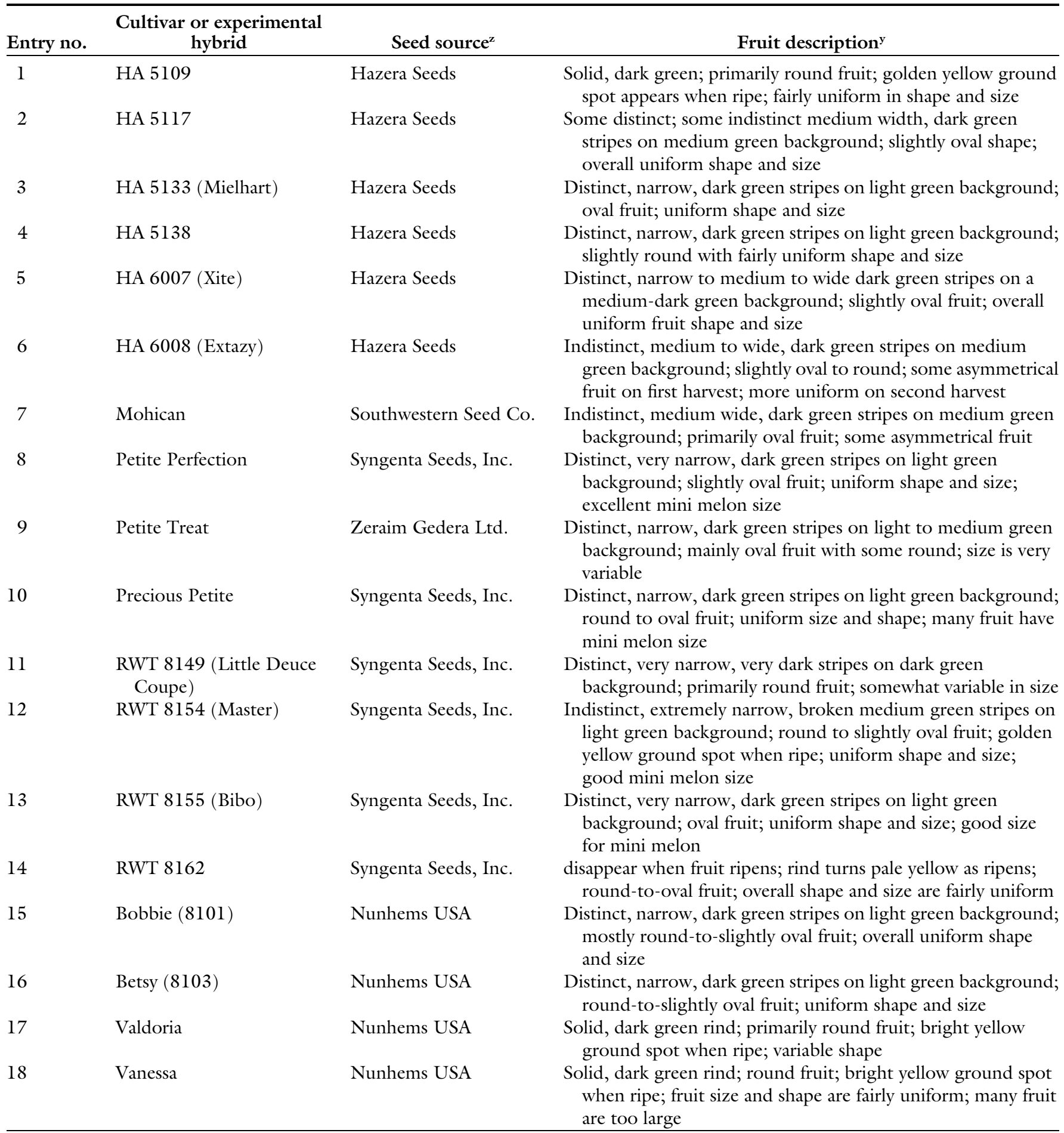

${ }^{2}$ Hazera Seed Ltd., El Segundo, CA; Southwestern Seeds Co., Casa Grande, AZ; Syngenta Seeds, Inc., Boise, ID; Zeraim Gedera Ltd., Ocala, FL; Nunhems USA, Parma, ID. yescription of the miniwatermelon fruits were provided by the seed companies.

2004. The soil was a Norfolk sandy loam (fine, loamy siliceous thermic Typic Paleudults). Soil samples were taken in the fall, and based on those readings the fertilizer program was determined by following the recommendations in the published standards for North Carolina
(Sanders, 2004). In North Carolina, fertilizer was incorporated into the bed on 6 Apr. before laying black polyethylene plastic (1.25 mil thick, 60 inches wide; Reddick Fumigants, Williamston, NC) on 6 Apr. 2004. Fumigant 1,3-dicloropropene/ chloropicrin (Telone C-17; Dow
Agrisciences, Indianapolis) was injected on 6 Apr. 2004 under the plastic mulch as it was being layed. Ethalfluralin (Curbit; Platte Chemical, Fremont, NE) herbicide at $3 \mathrm{pt} /$ acre was applied between the plastic mulched beds for weed control on 20 Apr. 2004. At transplanting, a starter 
solution was applied using $20 \mathrm{~N}-$ $8.8 \mathrm{P}-16.6 \mathrm{~K}(0.5 \mathrm{lb} / 50 \mathrm{gal}$ water $)$ and diazinon (Diazon 50W; United Agri Products-Loveland Products, Greeley, $\mathrm{CO}$ ) insecticide at $1.0 \mathrm{oz} /$ $35 \mathrm{gal}$ water for insect control. Trickle irrigation $[8 \mathrm{mil}$, 12 -inch emitter spacing, $0.24 \mathrm{gal} / \mathrm{h}$ (T-Tape; TSystems International, San Diego)] was used to irrigate and fertilize over the growing season. Fertigation was initiated 2 weeks after planting on 17 May 2004 and applied weekly until 2 Aug. 2004. Several pesticides were applied weekly to control insects and diseases according to the recommended published standards for North Carolina (Sanders, 2004). The weeds between plastic were controlled with a shielded sprayer with paraquat dichloride (Gramoxone; Syngenta Seeds, Boise, ID) on 22 May. Harvest 1 began 14 July, while Harvest 4 (the last harvest) was 26 Aug.

Charleston, SC. Transplants were seeded on 15 Mar. 2004 in square black trays [top 1.19 inch square, bottom 0.7 inch square, 2 inches deep (\#128; TLC Polyform, Atlanta, GA] using Metro Mix 360 soilless mix (Scotts Co., Marysville, $\mathrm{OH}$ ) on 6 Apr. 2004. The transplants were grown for 6 weeks using the seedless watermelon transplant production guide recommendations (Hassell and Schultheis, 2002). The field experiments were conducted at the Clemson University Coastal Research and Education Center (CREC), Charleston, SC. The soil was Yauhamah (Aquic Hapludults) fine loamy sand. Soil samples were taken in the fall and based on those readings the fertilizer program was determined by following the recommendations in the published standards for South Carolina (Sanders, 2004). In South Carolina, fertilizer was incorporated into the bed before laying black polyethylene plastic [ 1.25 mil thick, 66 inches wide (Reddick Fumigants, Williamston, NC)] on 10 March. Fumigant 1,3-dichloropropene and chloropicrin (Telone C-17) was injected on 10 March as the plastic mulch was being layed on the soil. Ethalfluralin and clomazone (Strategy; United Agri Products-Loveland Products) herbicides were applied at $6 \mathrm{pt} /$ acre between the plastic mulched beds for weed control on 20 Apr. At transplanting on 27 Apr., a starter solution was applied which contained $20 \mathrm{~N}-8.8 \mathrm{P}-16.6 \mathrm{~K}(0.5 \mathrm{lb} /$ 50 gal water) and diazinon (Diazon 50W; United Agri Products-Loveland Products) insecticide at $1.0 \mathrm{oz} /$ $35 \mathrm{gal}$ water for insect control. Trickle irrigation [8 mil, 12 -inch emitter spacing, $0.48 \mathrm{gal} / 100$ linear $\mathrm{ft}$ per hour (T-Tape)] was used to irrigate and fertilize over the growing season. Fertigation was initiated 1 week after planting on 4 May and applied weekly until 2 July. Fertigation rates and duration were applied according to recommended published for South Carolina (Sanders, 2004). Several pesticides were applied weekly to control insects and diseases according to the recommendations published for South Carolina (Sanders, 2004). Harvest began 20 June and ended 6 July.

Blackville, SC. The field experiment was conducted at the Clemson University Edisto Research and Education Center (ERDC), Blackville, SC. The watermelon beds were prepared and fertilizer was applied on 15-19 Mar. 2004. The soil was Dothan loamy sand (2\% to $6 \%$ slope, DaB series). Soil samples were taken in the fall, and based on those readings the fertilizer program was determined by following the published procedures for South Carolina (Sanders, 2004). Fertilizer was incorporated into the soil on 16 March. On 17 March, black polyethylene plastic $[0.7$ mil thick, 60 inches wide (Sonoco, Hartsville, SC)] was applied. The fumigant methyl bromide/chloropicrin (67:33; Great Lakes Chemical Corp., Lafayette, IN) was injected under the plastic at $23 \mathrm{lb} / 1000$ linear ft. Drip irrigation tubing [ 8 mil, 12 -inch emitter spacing, $0.48 \mathrm{gal} / 100$ linear $\mathrm{ft}$ per hour (T-Tape)] was applied at this time. Watermelon seeds were sown on 29 Mar. 2004 in square black trays [top 1.19 inch square, bottom 0.7 inch square, depth 2 inches (\#128; TLC Polyform, Inc.)]. The planting medium used was Metro-Mix 360 (Scotts Co., Marysville, OH). Seeded trays were kept in a germination room at $90{ }^{\circ} \mathrm{F}$ for $48 \mathrm{~h}$ and then moved to the greenhouse. Greenhouse temperatures were set for $65^{\circ} \mathrm{F}$ night and 75 ${ }^{\circ} \mathrm{F}$ day. On 22 Apr. 2004, $25 \mathrm{~d}$ after planting (DAP), the seedless watermelon transplants were moved to wire racks at the field before being transplanted in the field on 24 Apr. Drip irrigation was initiated at planting, two cycles per day. Daily fertigation through the drip system was begun on 2 May. Ethalfluralin and clomazone (Strategy) herbicides were applied at $3 \mathrm{pt} /$ acre on 11 May. Several pesticides were applied weekly to control insects and diseases according to published standards for South Carolina (Sanders, 2004). The watermelons were harvested three times; 28 June, 6 July, and 13 July 2004

Bradenton, FL. Seeds were planted in a peat-lite growing mix in planter flats $\left[1^{1 / 4} \times 1^{1} / 4 \times 2^{1} / 4\right.$-inch cells (Todd Planter flats; Speedling, Sun City, FL) ] on 2 Feb. The watermelon transplants were grown by a commercial plant grower. The soil was a Myakka fine sand (sandy, silicaceous hypothermic Alfic haplaguod). Soil samples were taken in the spring and based on those readings the fertilizer program was determined by following the recommendations in the published recommendations for Florida (Olson and Simonne, 2004). The beds were prepared in midFebruary, formed, and fumigated with methyl bromide/chloropicrin (67:33; Great Lakes Chemical Corp.) at $350 \mathrm{lb} /$ acre (treated). Banded fertilizer was applied in shallow grooves on the bed shoulders after the beds were pressed and before the black polyethylene mulch was applied. The final beds were 32 inches wide and 8 inches high and were spaced on 9 - $\mathrm{ft}$ centers with four beds between seepage irrigation/drainage ditches, which were on $41-\mathrm{ft}$ centers. The transplants were set in holes punched in the polyethylene mulch on 2 March at 1.5 - $\mathrm{ft}$ in-row spacing that provided $13.5 \mathrm{ft}^{2} /$ plant. Weed control in row middles was by cultivation and applications of paraquat dichloride (Gramoxone) herbicide. Pesticides were applied as needed using Florida grower recommendations (Olson and Simonne, 2004). Watermelons were harvested on 24 May and I June 2004

Quincy, FL. Seeds were planted in a peat-lite growing mix in expanded polystyrene flats of inverted pyramid design $\left[11 / 2 \times 1^{1} / 2 \times 21 / 2\right.$ inch cells (Todd Planter flats)] on 23 Feb. Soil type was Orangeburg loamy fine sand (fine loamy, siliceous, thermic, Typic Paleudults). Soil samples were 
taken in the fall, and based on those readings the fertilizer program was determined by following the recommendations in the published standards for Florida (Olson and Simonne, 2004). Fertilizer was applied (modified, broadcast) before beds were formed. Beds were pressed, fumigated with methyl bromide/chloropicrin $(67: 33)$ at $350 \mathrm{lb} / \mathrm{acre}$ (treated), drip tape [10 mil, 12-inch emitter spacing, $0.5 \mathrm{gal} / 100 \mathrm{ft}$ per minute (Twin Wall IV; Chapin Watermatics, Watertown, NY)] was applied, as was the black polyethylene mulch [1.25 mil thick, 60-inches wide; (Pliant Corp., Bloomington, IN)]. The final beds were 36 inches wide and 6 inches high. The transplants were set on 25 Mar. Weed control in row middles was by cultivation and applications of paraquat dichloride (Gramoxone) herbicide, halosulfuron (Sandea; Gowan Co., Yuma, AZ) herbicide, and ethalfluralin (Curbit) herbicide. Pesticides were applied as needed using the published standards for Florida (Olson and Simonne, 2004). Watermelons were harvested on 21 and 28 June and 8 July 2004. Quality measurements were taken from fruit harvested on 21 June.

\section{Results}

T O T A L A N D P E R C E T MARKETABLE YIELDS. There was a significant cultivar-by-location interaction, suggesting that cultivar and experimental hybrids responded differently at each of the five locations (Table 2); however, among the 18 cultigens tested, some were unaffected by location (Table 3). For total fruit number, RWT 8162 was one of the highest-yielding experimental hybrids at all locations, while 'Bibo' and 'Vanessa' were among the highest- yielding cultigens at four of the five locations. 'Petite Treat' yields were consistently low at all locations. With respect to total yields, 'Bobbie', 'Betsy', 'Extazy', and HA 5138 were among the lowest-yielding at four of the five locations. As with total yields, the percentage of marketable fruit was similar for some cultigens across locations. Individual fruit were considered marketable if they were between 3 and $9 \mathrm{lb}$. Cultivars Mielhart and Little Deuce Coupe produced the highest percentage of marketable fruit at all locations. 'Master', 'Bibo', 'Petite Perfection', and 'Precious Petite' had high percentages of marketable fruit at four of the five locations. The experimental hybrids that consistently produced melons that failed to fall within the acceptable marketable weight range were HA 5138 and HA 5117. 'Petite Treat' and 'Valdoria' were among the lowest at four of the five locations.

Percent distribution of MELON SIZE. There was significant cultivar by location interaction indicating that size distribution among some cultigens was affected by the growing environment (Table 2). In two locations (Charleston and Bradenton), there were no significant differences among cultigens in the $<3$-lb class (cull melons) (Table 3 ). Edisto, SC, and Kinston, NC, had two cultigens, Bibo and RWT 8162, that had a higher percentage of small (cull) fruit. In Kinston, 'Precious Petite' also produced a significantly higher percentage of small cull fruit than the other cultivars. There were significant differences among cultigens at Quincy. 'Master' produced $42 \%$ of its yield in the $\leq 3-1 b$ fruit category followed by 'Bibo' (29\%), 'Precious Petite' and 'Petite Perfection' (25\%), and RWT 8162 (22\%).
Within the smallest percent marketable (3.1-5.0 lb) class, three cultigens consistently produced the greatest percentage of small marketable melons. 'Bibo' consistently produced a greater percentage of fruit in the small marketable size category at all locations, whereas 'Precious Petite' and RWT 8162 produced a greater percentage in four out of the five locations. Within the medium-sized marketable (5.1-7 lb) class, 'Mielhart' and RWT 8149 consistently produced a greater percentage over all locations, whereas HA 5109, 'Xite', 'Mohican', 'Bobbie', and 'Vanessa' produced a higher percentage at four out of the five locations. Within the large-sized marketable (7.1-9 lb) class, HA 5117 produced a significantly greater percentage over four locations, whereas HA 5109, 'Extazy', 'Mohican', 'Petite Treat', and 'Valdoria' produced a greater percentage of large marketable fruit at three of the five locations. In the $>9$-lb class (cull melons), HA 5138 produced the greater percentage of fruit at all locations, whereas HA 5117, 'Bobbie', and 'Valdoria' produced a greater percentage at four of the five locations. Fruit weighing $>9 \mathrm{lb}$ would likely not be marketable and not fit the criteria for miniwatermelon size.

QuALITY VARIABLES. There was a significant cultivar-by-location interaction for the percentage soluble solids and the presence of dark seeds, suggesting that some cultigens responded differently at each of the five locations (Table 4). 'Master', RWT 8162, and 'Betsy' consistently produced high soluble solids readings at all five locations (Table 5). 'Bobbie' and 'Bibo' produced high soluble solid readings at four of the five locations. The presence of dark

Table 2. Percentages of the treatment sum of squares of the model partitioned into main and interaction effects for miniwatermelon yield and quality variables of 18 cultivars or experimental hybrids grown in five locations within the southeastern United States.

\begin{tabular}{|c|c|c|c|c|c|c|c|}
\hline \multirow{2}{*}{$\begin{array}{l}\text { Source of } \\
\text { variation }\end{array}$} & \multirow{2}{*}{$\begin{array}{c}\text { Total watermelons } \\
(\text { no./plot })^{\mathrm{z}}\end{array}$} & \multirow{2}{*}{$\begin{array}{l}\text { Marketable yield } \\
(\% \text { of total yield })\end{array}$} & \multicolumn{5}{|c|}{ Distribution of melons among wt classes $(\%)^{y}$} \\
\hline & & & $\leq 3.0 \mathrm{lb}$ & $3.1-5.0 \mathrm{lb}$ & $5.1-7.0 \mathrm{lb}$ & $7.1-9.0 \mathrm{lb}$ & $\geq 9.1 \mathrm{lb}$ \\
\hline Replication & 7 & 1 & 6 & 1 & 2 & 5 & 3 \\
\hline Cultivar $(\mathrm{C})$ & $7 * *$ & $33^{* *}$ & $17 * *$ & $73 * *$ & $21 * *$ & $51 * *$ & $48^{* *}$ \\
\hline $\mathrm{C} \times \mathrm{L}$ & 17 ** & $25 * *$ & $18 * *$ & $8 * *$ & $29 * *$ & $17 * *$ & $17 * *$ \\
\hline Error & 19 & 31 & 26 & 13 & 37 & 22 & 20 \\
\hline
\end{tabular}

${ }^{\mathrm{z}}$ Includes number of marketable and cull melons. Plots consisted were $15 \mathrm{ft}(4.6 \mathrm{~m})$ in length, 10 plants per plot.

${ }^{y}$ Fruit were divided into five categories based on weight ranges from $\leq 3.0 \mathrm{lb}$ (culls), $3.1-9.0 \mathrm{lb}$ (marketable), and $\geq 9.1 \mathrm{lb}$ (culls); $1 \mathrm{lb}=0.4536 \mathrm{~kg}$.

${ }^{* *} F$ values significant at $P=0.01$. 
Table 3. Miniwatermelon yield and quality variables of 18 cultivars or experimental hybrids planted in five locations within the southeastern United States.

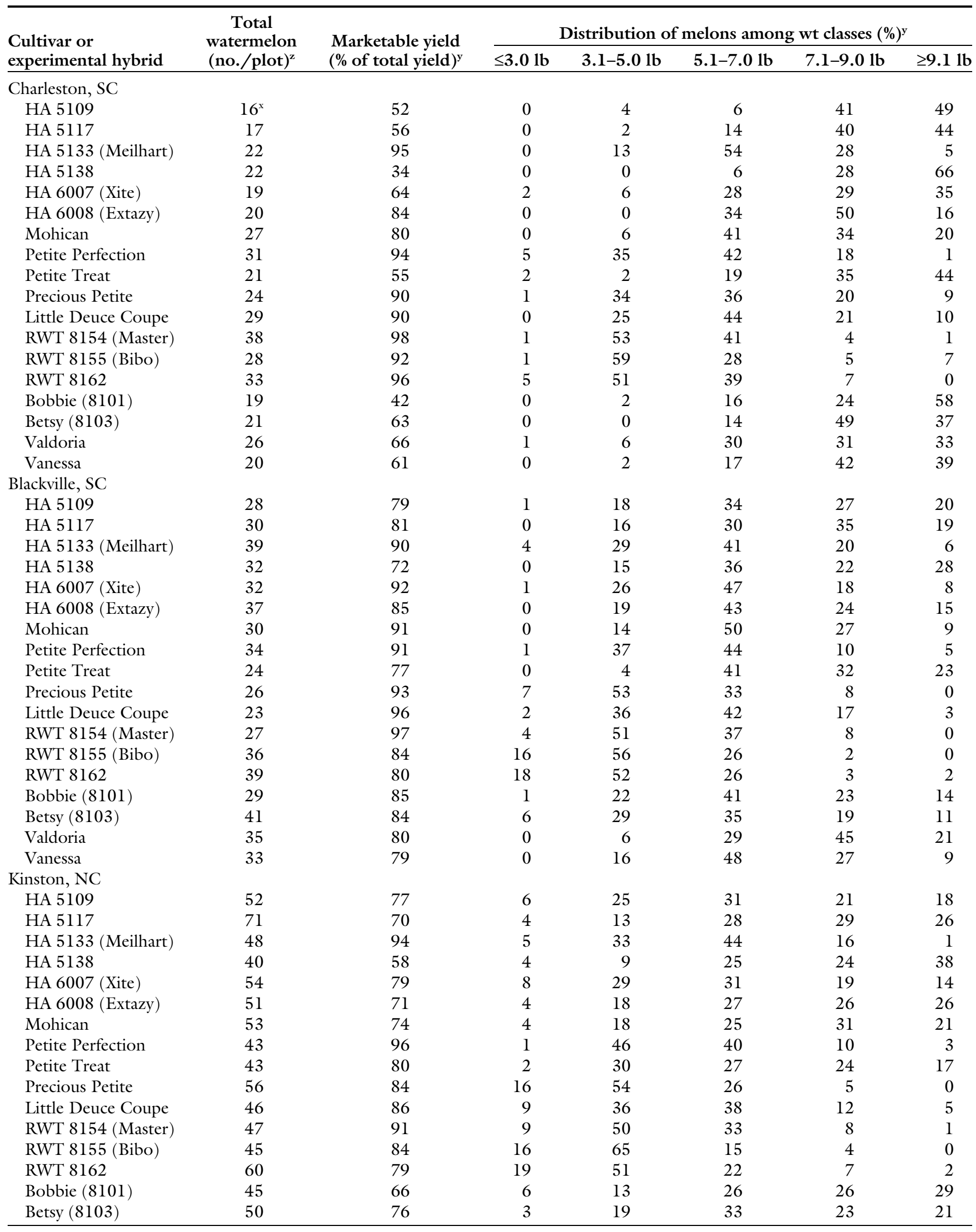

(Continued on next page) 
Table 3. (Continued) Miniwatermelon yield and quality variables of 18 cultivars or experimental hybrids planted in five locations within the southeastern United States.

\begin{tabular}{|c|c|c|c|c|c|c|c|}
\hline $\begin{array}{l}\text { Cultivar or } \\
\text { experimental hybrid }\end{array}$ & $\begin{array}{c}\text { Total } \\
\text { watermelon } \\
\text { (no./plot) }{ }^{\mathrm{z}}\end{array}$ & $\begin{array}{l}\text { Marketable yield } \\
(\% \text { of total yield })^{\mathrm{y}}\end{array}$ & \multicolumn{5}{|c|}{ Distribution of melons among wt classes $(\%)^{\mathrm{y}}$} \\
\hline Valdoria & 55 & 71 & 4 & 21 & 28 & 22 & 25 \\
\hline \multicolumn{8}{|l|}{ Quincy, FL } \\
\hline HA 5109 & 28 & 85 & 7 & 12 & 39 & 34 & 8 \\
\hline HA 5138 & 25 & 55 & 7 & 13 & 18 & 23 & 38 \\
\hline HA 6007 (Xite) & 27 & 84 & 15 & 26 & 42 & 16 & 1 \\
\hline HA 6008 (Extazy) & 28 & 66 & 14 & 10 & 24 & 33 & 20 \\
\hline Mohican & 29 & 66 & 11 & 12 & 26 & 28 & 23 \\
\hline Petite Perfection & 30 & 75 & 25 & 51 & 22 & 2 & 0 \\
\hline Petite Treat & 26 & 71 & 16 & 22 & 28 & 22 & 13 \\
\hline RWT 8155 (Bibo) & 43 & 71 & 29 & 61 & 10 & 0 & 0 \\
\hline RWT 8162 & 32 & 78 & 22 & 48 & 28 & 3 & 0 \\
\hline Bobbie (8101) & 19 & 77 & 7 & 20 & 31 & 26 & 16 \\
\hline Betsy $(8103)$ & 29 & 78 & 13 & 15 & 38 & 25 & 9 \\
\hline Valdoria & 29 & 57 & 17 & 6 & 11 & 40 & 26 \\
\hline Vanessa & 32 & 82 & 13 & 16 & 32 & 35 & 5 \\
\hline \multicolumn{8}{|l|}{ Bradenton, FL } \\
\hline HA 5109 & 39 & 76 & 2 & 19 & 39 & 18 & 22 \\
\hline HA 5117 & 33 & 72 & 4 & 15 & 45 & 12 & 25 \\
\hline HA 5133 (Meilhart) & 25 & 92 & 2 & 26 & 44 & 23 & 5 \\
\hline HA 5138 & 23 & 69 & 0 & 5 & 22 & 42 & 31 \\
\hline HA 6007 (Xite) & 27 & 85 & 1 & 12 & 47 & 26 & 14 \\
\hline RWT 8155 (Bibo) & 34 & 94 & 6 & 70 & 21 & 3 & 0 \\
\hline RWT 8162 & 35 & 95 & 4 & 58 & 32 & 4 & 2 \\
\hline Bobbie (8101) & 33 & 78 & 0 & 9 & 40 & 30 & 22 \\
\hline Betsy $(8103)$ & 29 & 88 & 0 & 18 & 53 & 17 & 12 \\
\hline Valdoria & 32 & 62 & 2 & 9 & 29 & 24 & 37 \\
\hline Vanessa & 52 & 84 & 3 & 17 & 47 & 20 & 13 \\
\hline
\end{tabular}

${ }^{2}$ Includes number of marketable and cull watermelons. Plots consisted were $15 \mathrm{ft}$ in length, 10 plants per plot.

${ }^{y}$ Fruit were divided into five categories based on weight ranges from $\leq 3.0 \mathrm{lb}$ (culls), $3.1-9.0 \mathrm{lb}$ (marketable), and $\geq 9.1 \mathrm{lb}$ (culls); $1 \mathrm{lb}=0.4536 \mathrm{~kg}$.

${ }^{x}$ LSD values $(\alpha=0.05)$ for mean separation among cultivars were $9,12,17,15,17,14$, and 15, for total yield, marketable yield, and each weight range, respectively. Analysis was performed after arcsin transformation of the percentage data.

seedcoats was recorded at all locations with the exception of the Bradenton site (Table 6). There was no consistent response for a given cultivar across all locations. All cultigens produced dark seeds at one of the four locations. Blackville produced the least and Quincy produced the highest number of dark seeds among cultivars. Rind thicknesses were significant for the main effects of location and cultivar, but not the interaction, while fruit shape index rating was significant only for cultivar (Table 4). The rind thickness measurements showed more of a cultivar response than location. In general, rind thickness was not uniform around the fruit and seemed to be thicker at the stem end and thinnest at the blossom end (Table 7). The thickest rind was measured in HA 5138, whereas the thinnest were found in 'Petite Perfection', 'Little Deuce Coupe', 'Master', 'Bibo', and RWT 8162. Location affected rind thickness, with Blackville producing the thickest rind of the four locations (Table 8). Fruit shape of most cultigens was generally round. The exceptions were 'Meilhart', HA 5138, 'Mohican', 'Petite Treat', 'Little Deuce Coupe', and 'Bibo', which tended to be slightly oval (Table 7 ).

\section{Discussion}

TOTALAN D P ERCEN T MARKETABLE YIELDS. Total yields 
varied significantly among locations (Table 3 ) and were likely due to the number of harvests made per plot. Kinston had as many as seven harvests on some plots. Other locations had only three or four harvests. For this reason, the data were analyzed on a percentage basis to provide a better understanding as to how the cultigens produced in multiple locations. It is well documented that cultivar production and quality will be different in various environments and that local cultivar trials are needed before recommendations are made (Thompson and Kelly, 1957). In this study, we found that of the 18 cultigens tested, eight ('Meilhart', 'Petite Perfection', 'Precious Petite', 'Little Deuce Coupe', RWT 8162, 'Master',
'Bibo', and 'Vanessa') that were consistently among the top-yielding and four (HA5138, HA 5117, 'Petite Treat', and 'Valdoria') were consistently among the low-yielding cultigens. These cultigens had a consistent yield response regardless of location.

Percent distribution of MELON SIZE. When developing a market for miniwatermelons, it is extremely important to select cultivars that will consistently produce uniform fruit size. The consumer, as well as the packer/shipper, must have a product that consistently meets specifications for packaging and handling (USDA, 2004). Within the small marketable melon category (3.1-5 lb), 'Bibo', 'Precious Petite', and RWT 8162 produced a uniform fruit over the five locations. Within the medium marketable melon category (5.1-7 lb), 'Meilhart', 'Little Deuce Coupe', HA 5109, 'Xite', 'Mohican', SR 8101, and 'Vanessa' produced a uniform fruit size over the five locations. The largest marketable class $(7.1-9 \mathrm{lb})$ is too large to be considered in the miniwatermelon market. HA 5117, HA 5109, 'Extazy', 'Mohican', 'Petite Treat', and 'Valdoria' produced more fruit in the larger category. Those cultigens that produced melons that were consistently $>9 \mathrm{lb}$ were HA 5138, HA 5117, 'Bobbie', and 'Valdoria'. These cultivars and advanced experimental hybrids would be considered too large to be

Table 4. Percentages of the treatment sum-of-squares of the model, partitioned into main and interaction effects, for miniwatermelon quality variables of 18 cultivars or experimental hybrids grown in five locations in the southeastern United States. ${ }^{\mathrm{z}}$

\begin{tabular}{|c|c|c|c|c|c|c|c|}
\hline \multirow{2}{*}{$\begin{array}{l}\text { Source of } \\
\text { variation }\end{array}$} & \multirow[b]{2}{*}{$\operatorname{SSC}(\%)^{y}$} & \multirow{2}{*}{$\begin{array}{l}\text { Seed index } \\
(0-3 \text { scale })^{x}\end{array}$} & \multicolumn{4}{|c|}{ Rind thickness (inches) ${ }^{\mathrm{z}}$} & \multirow{2}{*}{$\begin{array}{l}\text { Fruit shape index } \\
\quad(1-2 \text { scale })^{\mathrm{w}}\end{array}$} \\
\hline & & & Stem end & Blossom end & Top & Bottom & \\
\hline Rep. & 1 & 2 & 0 & 0 & 2 & 1 & 0 \\
\hline Cultivar (C) & $11 * *$ & $14^{* *}$ & $60 * *$ & $60 * *$ & $71 * *$ & $74 * *$ & $36 * *$ \\
\hline $\mathrm{C} \times \mathrm{L}$ & $15^{* *}$ & $34^{* *}$ & 0 & 8 & 9 & 10 & 0 \\
\hline Error & 16 & 34 & 20 & 20 & 16 & 14 & 64 \\
\hline
\end{tabular}

${ }^{z}$ Five randomly selected watermelons per cultivar per plot and per location were cut from blossom end to stem end before measurements were taken; 1 inch $=2.54 \mathrm{~cm}$.

ySoluble solids concentration (SSC) measured with refractometer from a sample taken between blossom and stem end.

${ }^{x}$ Each cut fruit was rated for seediness using the following scale: 0 , no seeds; $1,<10$ seeds; $2,>10$ but $<50$ seeds; $3,>50$ seeds.

"Each fruit was rated according to shape: 1, round; and 2, oblong.

${ }^{*}$ F values significant at $P=0.01$.

Table 5. Miniwatermelon total soluble solids concentration (\%) of five randomly samples marketable melons per treatment on 18 cultivars or experimental hybrids planted in five locations within the southeastern United States. ${ }^{\mathrm{Z}}$

\begin{tabular}{|c|c|c|c|c|c|}
\hline \multirow{2}{*}{$\begin{array}{l}\text { Cultivar or } \\
\text { experimental hybrid }\end{array}$} & \multicolumn{5}{|c|}{ Location } \\
\hline & Charleston, SC & Blackville, SC & Kinston, NC & Quincy, FL & Bradenton, FL \\
\hline HA 5109 & $10.7^{y}$ & 10.1 & 11.9 & 12.8 & 10.9 \\
\hline HA 5133 (Meilhart) & 10.8 & 10.0 & 10.7 & 11.7 & 11.8 \\
\hline HA 5138 & 11.7 & 10.1 & 11.8 & 12.8 & 11.6 \\
\hline HA 6007 (Xite) & 11.7 & 10.4 & 11.9 & 12.6 & 12.4 \\
\hline Petite Perfection & 11.6 & 10.8 & 11.9 & 12.6 & 13.5 \\
\hline Petite Treat & 10.6 & 10.0 & 10.6 & 12.4 & 12.9 \\
\hline Precious Petite & 11.6 & 10.6 & 11.5 & 11.7 & 12.9 \\
\hline Little Deuce Coupe & 10.7 & 10.6 & 11.8 & 13.6 & 13.0 \\
\hline RWT 8154 (Master) & 11.9 & 10.6 & 12.2 & 13.2 & 14.7 \\
\hline RWT 8155 (Bibo) & 11.2 & 10.9 & 11.8 & 13.6 & 13.2 \\
\hline Valdoria & 10.7 & 9.9 & 11.2 & 13.1 & 12.4 \\
\hline Vanessa & 10.7 & 10.0 & 11.3 & 12.9 & 12.3 \\
\hline
\end{tabular}

${ }^{\mathrm{z}}$ Each fruit was cut from blossom end to stem end, center section sampled for soluble solid concentration measured using a refractometer.

${ }^{{ }^{\prime} L S D}$ values $(\alpha=0.05)$ for mean separation among cultivars and locations was 1.0 for soluble solid concentrations. 
Table 6. Miniwatermelon seed index ratings of five randomly samples marketable melons per treatment on 18 cultivars or experimental hybrids planted in four diverse locations within the southeastern United States.

\begin{tabular}{lcccc}
\hline \multirow{2}{*}{$\begin{array}{l}\text { Cultivar or } \\
\text { experimental hybrid }\end{array}$} & \multicolumn{4}{c}{ Location } \\
\cline { 2 - 5 } & Charleston, SC & Blackville, SC & Kinston, NC & Quincy, FL \\
\hline HA 5109 & $2.40^{\mathrm{y}}$ & 0.27 & 0.33 & 0.27 \\
HA 5117 & 0.07 & 0.00 & 0.07 & 0.13 \\
HA 5133 (Meilhart) & 0.00 & 0.07 & 0.27 & 0.40 \\
HA 5138 & 0.07 & 0.07 & 0.47 & 0.42 \\
HA 6007 (Xite) & 0.33 & 0.07 & 0.47 & 0.20 \\
HA 6008 (Extazy) & 0.00 & 0.00 & 0.27 & 0.13 \\
Mohican & 0.13 & 0.07 & 0.40 & 0.53 \\
Petite Perfection & 0.13 & 0.00 & 0.17 & 0.53 \\
Petite Treat & 0.40 & 0.00 & 0.00 & 0.57 \\
Precious Petite & 0.00 & 0.07 & 0.07 & 0.60 \\
Little Deuce Coupe & 0.80 & 0.00 & 0.13 & 0.73 \\
RWT 8154 (Master) & 0.67 & 0.07 & 0.20 & 0.40 \\
RWT 8155 (Bibo) & 0.20 & 0.07 & 0.20 & 1.00 \\
RWT 8162 & 1.00 & 0.13 & 0.07 & 0.60 \\
Bobbie (8101) & 0.13 & 0.07 & 0.07 & 0.53 \\
Betsy (8103) & 0.67 & 0.00 & 0.27 & 0.60 \\
Valdoria & 0.27 & 0.07 & 0.27 & 0.47 \\
Vanessa & 0.47 & 0.00 & 0.20 & 0.60 \\
\hline
\end{tabular}

${ }^{2}$ Each fruit was cut from blossom end to stem end, center section, then rated for the presence of seeds using the following scale: 0 , no seeds; $1,<10$ seeds; $2,>10$ but $<50$ seeds; $3,>50$ seeds.

${ }^{\mathrm{y}}$ LSD values $(\alpha=0.05)$ for mean separation among cultivars and locations was 0.54 for seed index rating.

classed as a miniwatermelon but might be sold as an "ice box" watermelon.

Quality VARIABLES. Sugar levels must consistently meet expectations of consumers and buyers (USDA, 2004). Total soluble solids (\%) are used for determining sugar levels
(Maynard, 2001). We found five cultigens that provided consistently high soluble solids readings at each location, ('Master', RWT 8162, 'Betsy', 'Bobbie', and 'Bibo') (Table $5)$. Fruit produced at the two Florida locations had higher soluble solid readings than did the other locations.
The reason for this is still unknown; however, this may be due to light intensity, daylength, or soil types. Each of these can influence soluble solids concentration levels of different vegetables (Thompson and Kelly, 1957). The presence of black seeds is a major concern (Table 6). These are classified as seedless watermelons, and the presence of black seeds is unacceptable. In this study, we sampled only five fruit of each cultivar/experimental hybrid for internal quality but found dark seeds in all of the cultigens in at least one of the locations. In Quincy, all cultigens had at least one fruit with hard seed(s). However, hard seeds were prevalent at each of the other three locations as well. The cause leading to hard or black seeds is not known and warrants further investigation. There is some speculation that this is incited by plant stress early in the growing season, such as fertility, cold temperatures, or drought stress, as well as a genetic trait (X. Zhang, personal communication). Rind thickness and fruit shape do not appear to be influenced by test site location (Table 7 ). The Syngenta Seeds, Inc., cultigens have the thinnest rind. All the other cultigens produced melons with thicker rinds. In general, cultivars from Hazera Seed Ltd. (El Segundo, CA) appear to have thicker rind depth.

Table 7. Main effects of 18 cultivars or experimental hybrids (pooled over four southeastern locations) of five random marketable miniwatermelon samples per treatment on rind thickness variables ${ }^{\mathrm{z}}$ and fruit shape index. ${ }^{\mathrm{y}}$

\begin{tabular}{|c|c|c|c|c|c|}
\hline \multirow{2}{*}{$\begin{array}{l}\text { Cultivar or } \\
\text { experimental hybrid }\end{array}$} & \multicolumn{4}{|c|}{ Rind thickness (inches) } & \multirow{2}{*}{$\begin{array}{c}\text { Fruit shape index } \\
(1-2 \text { scale })\end{array}$} \\
\hline & Stem end & Blossom end & Top & Bottom & \\
\hline HA 5109 & $0.58 \mathrm{~b}-\mathrm{d}^{\mathrm{x}}$ & $0.54 \mathrm{bc}$ & $0.62 \mathrm{a}-\mathrm{c}$ & $0.62 \mathrm{a}-\mathrm{c}$ & $1.07 \mathrm{c}$ \\
\hline HA 5133 (Meilhart) & $0.51 \mathrm{e}-\mathrm{g}$ & $0.50 \mathrm{~cd}$ & $0.50 \mathrm{fg}$ & $0.49 \mathrm{e}$ & $1.47 \mathrm{a}$ \\
\hline HA 5138 & $0.68 \mathrm{a}$ & $0.60 \mathrm{a}$ & $0.65 \mathrm{a}$ & $0.67 \mathrm{a}$ & $1.33 \mathrm{ab}$ \\
\hline HA 6007 (Xite) & $0.60 \mathrm{~b}-\mathrm{d}$ & $0.59 \mathrm{ab}$ & $0.61 \mathrm{a}-\mathrm{d}$ & $0.62 \mathrm{a}-\mathrm{c}$ & $1.07 \mathrm{c}$ \\
\hline Petite Perfection & $0.33 \mathrm{~h}-\mathrm{j}$ & $0.31 \mathrm{gh}$ & $0.34 \mathrm{hi}$ & $0.33 \mathrm{fg}$ & $1.00 \mathrm{c}$ \\
\hline Petite Treat & $0.49 \mathrm{fg}$ & $0.49 \mathrm{~cd}$ & $0.55 \mathrm{~d}-\mathrm{f}$ & $0.56 \mathrm{~cd}$ & $1.53 \mathrm{a}$ \\
\hline Precious Petite & $0.39 \mathrm{~h}$ & $0.33 \mathrm{~g}$ & $0.38 \mathrm{~h}$ & $0.36 \mathrm{f}$ & $1.07 \mathrm{c}$ \\
\hline Little Deuce Coupe & $0.33 \mathrm{~h}-\mathrm{j}$ & $0.29 \mathrm{gh}$ & 0.32 hi & $0.32 \mathrm{fg}$ & $1.33 \mathrm{ab}$ \\
\hline RWT 8154 (Master) & $0.36 \mathrm{hi}$ & $0.30 \mathrm{gh}$ & $0.33 \mathrm{hi}$ & $0.36 \mathrm{f}$ & $1.00 \mathrm{c}$ \\
\hline Valdoria & $0.54 \mathrm{~d}-\mathrm{f}$ & $0.43 \mathrm{df}$ & $0.54 \mathrm{e}-\mathrm{g}$ & $0.54 \mathrm{de}$ & $1.00 \mathrm{c}$ \\
\hline Vanessa & $0.47 \mathrm{~g}$ & $0.42 \mathrm{ef}$ & $0.48 \mathrm{~g}$ & $0.48 \mathrm{e}$ & $1.07 \mathrm{c}$ \\
\hline
\end{tabular}

${ }^{\mathrm{z}}$ Each fruit was cut from blossom end to stem end before measurements were taken; 1 inch $=2.54 \mathrm{~cm}$.

${ }^{y}$ Each fruit was rated according to shape: 1 , round; and 2, oblong.

'Different letters in same column mean significantly different to Duncan's multiple range test at $P \leq 0.05$ 
Table 8. Main effects of location (pooled over 18 cultivars or experimental hybrids) of five randomly samples marketable miniwatermelons per treatment on rind thickness variables. ${ }^{\mathrm{z}}$

\begin{tabular}{lcccc}
\hline & \multicolumn{4}{c}{ Rind thickness of the fruit (inches) } \\
\cline { 2 - 5 } Location & Stem end & Blossom end & Top & Bottom \\
\hline Charleston, SC & $0.55 \mathrm{a}^{\mathrm{y}}$ & $0.42 \mathrm{~b}$ & $0.50 \mathrm{~b}$ & $0.49 \mathrm{~b}$ \\
Blackville, SC & $0.52 \mathrm{a}$ & $0.52 \mathrm{a}$ & $0.53 \mathrm{a}$ & $0.53 \mathrm{a}$ \\
Kinston, NC & $0.48 \mathrm{~b}$ & $0.42 \mathrm{~b}$ & $0.49 \mathrm{bc}$ & $0.49 \mathrm{~b}$ \\
Quincy, FL & $0.42 \mathrm{~b}$ & $0.40 \mathrm{~b}$ & $0.47 \mathrm{c}$ & $0.49 \mathrm{~b}$ \\
\hline
\end{tabular}

${ }^{2}$ Each fruit was cut from blossom end to stem end before measurements were taken; 1 inch $=2.54 \mathrm{~cm}$.

'Different letters in the same column mean significantly different to Duncan's multiple range test at $P \leq 0.05$.

The inbred used by Syngenta, for hybrids was similar for all the Syngenta Seeds, cultigens that we evaluated in this study (D. Liere, personal communication). Rind thickness was not constant at any of the four positions on the fruit for any of the cultigens tested. The thicker rind appears at the stem end, and the thinner rind was at the blossom end. Location had an effect, but only slightly (Table 8). Rind thickness also seems to be determined more by genetics than environment.

\section{Literature cited}

Arney, M., S.R. Fore, and R. Brancucci. 2006. Watermelon reference book. National Watermelon Promotion Board, Orlando, FL. 80 pp.

Barboza, D. 2003. Fresh from consumer polls, pint-size watermelons. 10 July 2005. <http://www.nytimes.com/ 2003/06/15/business/15MELO.html? pagewanted $=1$ andei $=500>$.
Hassell, R.L. and J.R. Schultheis. 2002. Seedless watermelon transplant production guide. I Feb. 2004. <http://www. clemson.edu/psapublishing/ppt_files/ Seedlesswatermelon.ppt $>$.

Kihara, H. 1951. Triploid watermelons. Proc. Amer. Soc. Hort. Sci. 58:217230.

Lucier, G. and C. Plummer. 2003. Vegetables and melons outlook. United States Department of Agriculture, VGS-2003. USDA, Washington, D.C.

Marr, C.W. and K.L.B. Gast. 1991. Reactions by consumers in a farmer's market to prices for seedless watermelon and ratings of eating quality. HortTechnology 1(1):105-106.

Maynard, D. 2003. New plants for Florida; watermelon. 4 Sept. 2005. <http:// www.edis.fias.ufl.edu/AG212>.

Maynard, D.N. and G.W. Elmstrom. 1992. Triploid watermelon production practices and cultivars. Acta Hort. 318:169-173.
Maynard, D.N. and D.L. Hopkins. 1999. Watermelon fruit disorders. HortTechnology 9(2):155-161.

D.N. Maynard (ed.). 2001. Watermelons: characteristics, production and marketing. ASHS Press, Alexandria, VA.

Motsenbocker, C.E. and R.A. Arancibia. 2002. In-row spacing influences triploid watermelon yields and crop value. HortTechnology 12:437-440.

NeSmith, D.S. and J.R. Duval. 2001. Fruit set of triploid watermelons as a function of distance from a diploid pollenizer. HortScience 36:60-61.

Olson, S.M. and E. Simonne. 2004. Vegetable production handbook for Florida. Bayer CropScience, Triangle Park, NC.

Sanders, D.C. (ed.). 2004. Vegetable crop guidelines for the southeastern U.S. 2004-2005. North Carolina Vegetable Growers Association. Helena Chemical Co., Memphis, TN.

Thompson, H.C. and W.C. Kelly. 1957. Vegetable crops. McGraw-Hill, New York.

U.S. Department of Agriculture. 1978. United States standards for grades of watermelon. USDA, Agricultural Marketing Service, Washington, D.C.

U.S. Department of Agriculture. 2004. Fresh fruit and vegetable shipments. Agricultural Marketing Service FVAS-4. 4 Sept. 2005. <http://www.ams.usda. gov/fv/mncs/shipsumm04.pdf $>$.

Walters, S.A. 2005. Honey bee pollination requirements for triploid watermelons. HortScience 40:1268-1270. 